\title{
Medium and large sized mammals of the Boqueirão da Onça, North of Bahia State, Brazil
}

\author{
Cláudia Bueno de Campos ${ }^{1,3}$; Carolina Franco Esteves ${ }^{1,4}$; Douglas de Matos Dias ${ }^{2,5}$ \& Flávio Henrique Guimarães Rodrigues ${ }^{2,6}$ \\ ${ }^{1}$ Instituto para a Conservação dos Carnívoros Neotropicais (Pró-Carnívoros). Atibaia, SP, Brasil. \\ ${ }^{2}$ Universidade Federal de Minas Gerais (UFMG), Instituto de Ciências Biológicas (ICB), Departamento de Biologia Geral (DBG), \\ Programa de Pós-Graduação em Ecologia, Conservação e Manejo da Vida Silvestre. Belo Horizonte, MG, Brasil. \\ ${ }^{3}$ ORCID: http://orcid.org/0000-0002-0255-1848. E-mail: campos.claudiab@gmail.com \\ ${ }^{4}$ ORCID: http://orcid.org/0000-0003-4564-4101. E-mail: carolfesteves@gmail.com \\ ${ }^{5}$ ORCID: http://orcid.org/0000-0001-9664-860X. E-mail: diasdm.bio@gmail.com (corresponding author) \\ ${ }^{6}$ ORCID: http://orcid.org/0000-0002-4797-0085. E-mail: rodriguesfhg@gmail.com
}

\begin{abstract}
The mosaic of protected areas of Boqueirão da Onça $\left(8.636 \mathrm{~km}^{2}\right)$, created in the north of Bahia state, is located in the Caatinga, an exclusively Brazilian biome, but exposed to a range of anthropic impacts that threaten its species and natural resources. Few data are available for various zoological groups in Caatinga, including mammals. In order to characterize the community of mammals of this region, considering species richness, we installed 80 camera-trap stations. With a sampling effort of 10,370 camera-days we recorded 28 species ( 22 wild and six domestic). Opportunistically, we recorded four mammals, resulting in a total richness of 32 species, five of which are included in the global list of endangered species, and seven in the national list. The results are significant, since the richness of wild mammals of the Boqueirão da Onça $(S=26)$ presented a high value when compared to other Caatinga localities. During the study we found evidence of human activities threatening the conservation of the region, such as poaching and deforestation. Therefore, there is an urgent need in the publication of the Management Plan of the recently created Boqueirão da Onça National Park, to minimize negative impacts on biodiversity and ensure the maintenance of ecological processes.
\end{abstract}

Key-Words. Caatinga; Camera-trap; Northeast Brazil; Threatened species; Tropical Dry Forest.

\section{INTRODUCTION}

The Caatinga is one of the largest and most distinguished Brazilian biomes representing almost $70 \%$ of the northeastern region and $11 \%$ of the national territory (Castelletti et al., 2003). The climate is semi-arid with scarce and irregular rains and the region consists of seasonally dry tropical forest composed of a mosaic xerophilic, deciduous, woody and thorny physiognomies (Costa et al., 2007; Albuquerque et al., 2012; Queiroz et al., 2017). Although it is considered one of the most important semi-arid regions in South America in terms of biodiversity, knowledge about its fauna and ecological processes is scarce when compared to other Brazilian biomes (Santos et al., 2011; Sunderland et al., 2015).

The biodiversity of the Caatinga has been affected by agriculture and livestock farming for centuries, especially with the consolidation of colonial process and the expansion of population to the northeastern backland ("sertão") in the $19^{\text {th }}$ century (Evangelista, 2011). Extensive livestock (overgrazing), poaching, mining, unsus- tainable wood extraction and low-tech agriculture are practiced by a densely and low-income population, largely dependent on natural resources (Gariglio et al., 2010, Ribeiro-Neto et al., 2016). These impacts on vegetation caused by anthropogenic factors have culminated in desertification nuclei in some regions of the Caatinga (Coimbra-Filho \& Câmara, 1996; Ribeiro-Neto et al., 2016), threatening the persistence of wildlife species (Oliveira \& Diniz-Filho, 2010; Oliveira et al., 2012). And the prospects are not very encouraging, considering the progress of the establishment of wind energy companies in the most preserved areas of the biome (Bernard et al., 2014; Dias et al., 2019).

The loss and modification of natural habitats have been considered the greatest threats to the conservation of the diversity and the main disturbing agent of the mammal communities (Cuarón, 2000; Porras et al., 2016). Medium and large sized mammals are key elements to the ecosystem, as they play an important role in forest maintenance and regeneration, as well as providing ecological services that are essential for the environment in 
structuring the biological communities (Cuarón, 2000; Jones \& Safi, 2011).

The intervention region of this study, the Boqueirão da Onça, is the largest continuum of preserved caatinga vegetation and one of the most representative regions of the biome (Dias et al., 2019). This continuity of habitats is important, particularly for the maintenance of large mammals, mainly carnivores, due to the need for extensive home ranges and specific resources to survive (Astete et al., 2008). During data collection, the study area was not officially a protected area, and the process of land use and occupation followed some current environmental laws. However, although there are already laws for the use of the area, many details still need to be written in the document that will guide the Management Plan in order to establish the norms, restrictions for the use and actions to be developed in the protected area and its surroundings. Meanwhile, we run up against time to delay the negative effects of human activities in the region, since its biodiversity is alien to human pressures such as poaching and conflicts between humans and large predators (Paula et al., 2013; Dias et al., 2019).

Therefore, we consider that the conservation of mammals and decision making regarding the management of natural areas begins with updated information on the composition of communities by including primary data in inventories and environmental impact assessment (Pardini et al., 2003, Silveira et al., 2010). The occurrence of iconic or flag species may be a preliminary indicator of the conservation status of the area and provides the direction of management and conservation strategies. In this study we aimed to characterize the mammal community in Boqueirão da Onça in terms of species richness (S) and to assess conservation status at the regional, national and global levels.

\section{MATERIALS AND METHODS}

\section{Study site}

The region of Boqueirão da Onça is located in the northern of Bahia State (Fig. 1), comprising the municipalities of Sento Sé, Umburanas, Campo Formoso, Juazeiro and Sobradinho. It is a continuum of approximately $9,000 \mathrm{~km}^{2}$ of preserved caatinga, recently declared a mosaic of Protected Areas (decree-laws 9,336/18 and 9,337/18), and considered a hotspot for biodiversity conservation within the biome (MMA, 2016). The mosaic is formed by the National Park (NP) Boqueirão da Onça $\left(3,469 \mathrm{~km}^{2}\right)$, with full protection by Federal Law № 9,985/2000 (permission only for indirect use of its natural resources), and the Environmental Protection Area (EPA) Boqueirão da Onça $\left(5.057 \mathrm{~km}^{2}\right)$, with sustainable use also by Federal Law № 9,985/2000 (part of the area with a degree of human occupation and permission for direct use). The climate of Boqueirão da Onça is predominantly semi-arid (Bsh type in the Köppen classification system), with mean temperature of $30^{\circ} \mathrm{C}$ and mean annual precipitation of $693 \mathrm{~mm}$ (Álvares et al., 2013a, b).
The caatinga vegetation in Boqueirão da Onça is a mosaic of deciduous woody vegetation, prickly shrubs and seasonally dry tropical forests (IBGE, 2012; Banda et al., 2016). Despite the predominance of Caatinga flora, there are regions with species belonging to Cerrado, Amazon and Atlantic Forest ecoregions (Siqueira Filho et al., 2012). The landscape is heterogeneous with "veredas" (physiognomy composed of palm trees and shrub-herbaceous vegetation and humid soil), extensive plateaus, saws and "boqueirões" (regional name for a deep valley dug by a river, with water or not during the wet season). The region is also rich in grottoes, or creeks and springs, and very few of them have accumulated water during the driest periods of the year, crucial for the wildlife.

\section{Sampling methodology}

Data collected for this investigation is part of two different studies, one from medium and large sized mammal species monitoring program to meet the condition for installation license of a wind farm (Enel Green Power and "Programa Amigos da Onça") (Study 1), and the second was part of a research about analysis of occupancy of the mammals of the Boqueirão da Onça (Study 2). For the Study 1 inspections along trails and camera trapping surveys (Tigrinus) were carried out from April 2016 until May 2017. The Study 2 counted only on the installation of camera traps (Ltl Acorn 5210A and Bushnell) carried out from January to July 2017.

Camera traps in both studies $(\mathrm{N}=80)$ were installed along dirt roads (poacher trails, human and animal paths), previously recognized as potential use of medium and large sized mammals and programmed to operate continuously ( $24 \mathrm{~h} /$ day) taking pictures or shooting video (minimum interval of $30 \mathrm{~s}$ ). Recorded observations were considered independent each photo or video obtained at each camera trap station every 1 hour. In the Study 2, we randomly selected 60 points to establish the sampling sites. The cameras were then distributed to ensure that two adjacent sites were at least $1.5 \mathrm{~km}$ apart.

Also, for the Study 1 all direct (live or dead mammals) and indirect evidences (e.g., scats, tracks, scent marks, vocalization) obtained through inspections along trails were considered a record (Wemmer et al., 1996). Tracks of medium and large sized mammals were identified in loco, whenever possible, and when necessary, photographed with a standard measuring instrument for identification in comparison with the specialized literature (e.g., Borges \& Tomás, 2008; Becker \& Dalponte, 2013). In addition, due to the non-existence of small mammal species surveys in the study area, we considered the opportunity to cite some species recorded during our studies. The taxonomic classification was based on Wozencraft (2005) and Schiaffini et al. (2013) for Mephitidae; Kitchener et al. (2017) for Felidae; and Wilson \& Reeder (2005) for all other groups. The conservation status of each species was obtained from the red lists of the International Union for Conservation of Nature (IUCN), of the Brazilian Environment Ministry (MMA, 2018), and in Cassano et al. (2017). 

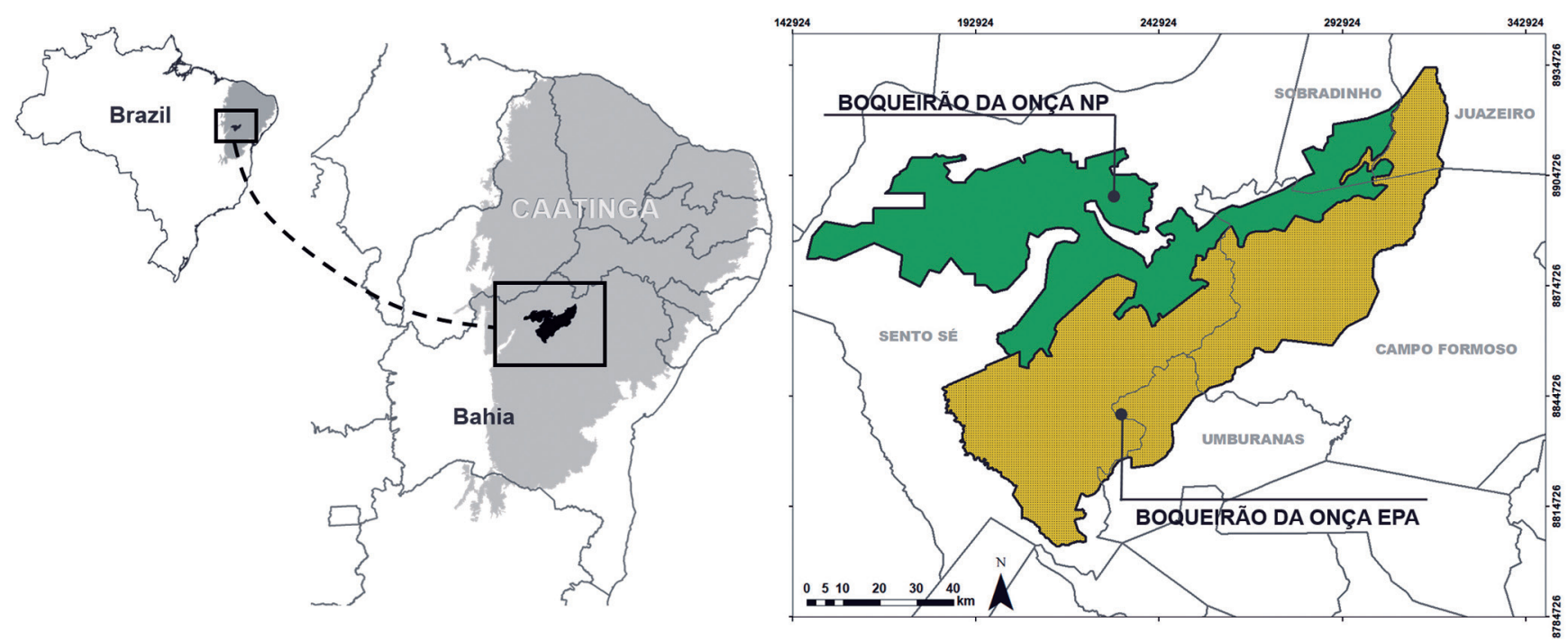

Figure 1. Mosaic formed by the National Park (NP) Boqueirão da Onça and the Environmental Protection Area (EPA) Boqueirão da Onça. Insertions on the left indicate the distribution of the Caatinga biome in northeastern Brazil and the location of the study area in the north of Bahia State, Brazil.

\section{RESULTS}

With a total of 80 sampling sites, the sample efforts spent by both studies were $(8,570+1,800) 10,370$ traps $^{*}$ day for camera-trap and $120 \mathrm{~km}$ for trail. We recorded 32 species of mammals in Boqueirão da Onça, 26 wild and six domestics $(3,654$ independent records), being nine species threatened at the regional level, seven at the national level and five of them globally threatened of extinction (Fig. 2; Table 1). We recorded opportunistically two primates, Alouatta caraya (Humboldt, 1812) and Callithrix jacchus (Linnaeus, 1758), one carnivore Galictis cuja (Molina, 1782) and one frugivore Tayassu pecari (Link, 1795).

\section{DISCUSSION}

The richness of medium and large terrestrial mammals of the Boqueirão da Onça $(S=26)$ presented a high value when compared to other localities, since recent inventories carried out in the Caatinga indicated the occurrence between seven and 29 species (Guedes et al., 2000; Freitas et al., 2011; Rocha et al., 2014; Dias \& Bocchiglieri, 2016; Deiciellos, 2016; Dias et al., 2017; Freitas et al., 2017; Pereira \& Peixoto, 2017; Marinho et al., 2018).

The number of species recorded in Boqueirão da Onça (this study) corresponds to $74 \%$ of medium and large size mammals found in the same region based on Paula et al. (2011), adding one more species to their list (D. albiventris). Moreover, according to the most recent compilation of the Caatinga mastofauna (Carmignotto \& Astúa, 2017), the number of species recorded in the present study represents $27 \%$ of the non-volant mammals that occur in the biome. A diverse set of habitats along with a low human density enables the maintenance of a rich mastofauna in this part of the Caatinga. This makes the Boqueirão da Onça a priority area for conservation (MMA, 2016).
However, its biodiversity is under imminent threat due to a number of anthropogenic impacts, and in recent years, this condition was aggravated because of intense changes in land use (Dias et al., 2019). Among the endangered species of Boqueirão da Onça, carnivores make up the majority, which is not surprising given that this group is particularly vulnerable due to intrinsic biological characteristics, such as large body sizes, requirements for large home ranges, low densities and slow population growth rates (Crooks et al., 2011). In many parts of the world, large predators are threatened by loss and fragmentation of habitats, conflicts with livestock breeders and poachers (Chapron et al., 2014; Di Minin et al., 2016), by directly removing wild predators or by indirectly depleting a wide variety of their preys (Karanth \& Chellam, 2009). In Boqueirão da Onça, the carnivores are exposed to all these impacts and, in addition, the establishment of wind farms also pose a potential threat (Dias et al., 2019).

A wind farm not only involves turbines accidents with animals but also a series of cumulative and indirect impacts associated with these infrastructures, such as sound and visual disturbances, vibration, microclimatic changes, vehicles traffic, barrier and corridor effect, electromagnetic field generation, as well as the fragmentation of habitats, which, together with the opening of roads, facilitates the access of poachers in areas formerly remote (Helldin et al., 2012; Costa et al., 2017).

The high number of records of domestic species in the natural habitats of our study area is also of concern. Particularly dogs can cause serious damage to native mammals, since they are related to predation (Campos et al., 2007; Lacerda et al., 2009), restriction on distribution (Lacerda et al., 2009; Massara et al., 2018) and disseminating diseases (Curi et al., 2016). Considering the ecological importance and the degree of threat to which mammals are subjected (Di Marco et al., 2014), it is crucial to ensure their protection. In this sense, the creation of protected areas has been the most efficient strategy, 
since its objective is the long-term conservation of nature, ecosystem services and the associated cultural values (Dudley, 2008). Thus, the focus of protected areas for the conservation of threatened species has been a powerful argument to justify their establishment, especially in developing countries (Athreya et al., 2013).
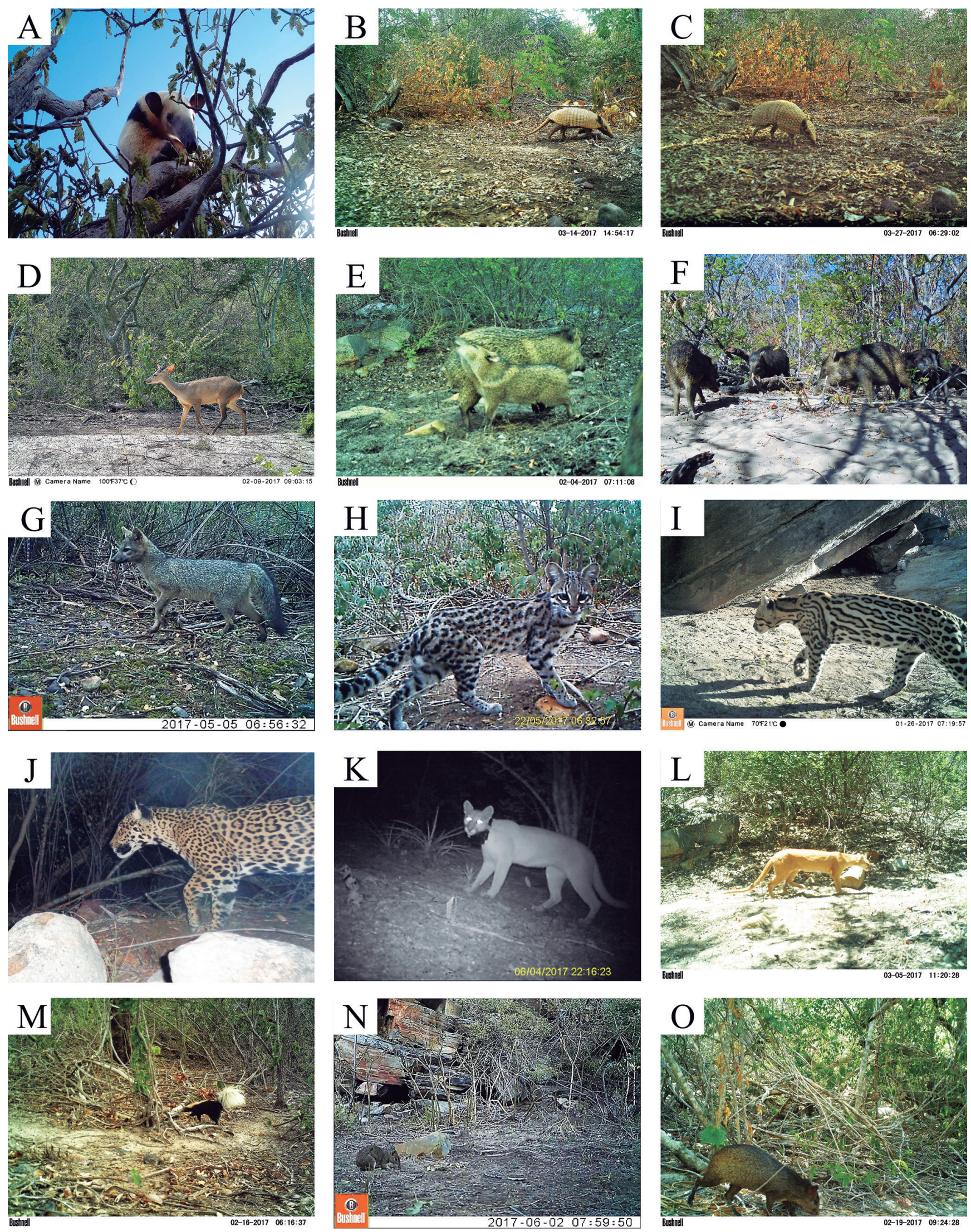

Figure 2. Mammals registered in Boqueirão da Onça, Bahia State, northeastern Brazil. (A) Tamandua tetradactyla; (B) Euphractus sexcinctus; (C) Tolypeutes tricinctus; (D) Mazama gouazoubira; (E) Pecari tajacu; (F) Tayassu pecari; (G) Cerdocyon thous; (H) Leopardus tigrinus; (I) Leopardus pardalis; (J) Panthera onca; (K) Puma concolor; (L) Herpailurus yagouaroundi; (M) Conepatus semistriatus; (N) Kerodon rupestris; (0) Dasyprocta nigriclunis. 
Table 1. Relation of mammal species recorded in the Boqueirão da Onça, Bahia, Brazil. Records from camera trap (Ct), visual (Vi), tracks (Tr), burrows (Bu), scat (Sc), and threat categories: Least concern $=\mathrm{LC}$; Near threatened $=\mathrm{NT}$; vulnerable $=\mathrm{VU}$; Endangered $=\mathrm{EN}$; Critically endangered $=\mathrm{CR}$.

\begin{tabular}{|c|c|c|c|c|c|c|}
\hline Species & Popular name & Camera trap Records & Record type & Bahia & Brazil & IUCN \\
\hline \multicolumn{7}{|l|}{ DIDELPHIMORPHIA } \\
\hline Didelphis albiventris ${ }^{1,2}$ & Opossum & 47 & $\mathrm{Ct}, \mathrm{Vi}$ & - & - & $\mathrm{LC}$ \\
\hline \multicolumn{7}{|l|}{ PILOSA } \\
\hline Myrmecophaga tridactyla ${ }^{2}$ & Giant Anteater & 1 & $\mathrm{Ct}$ & VU & VU & VU \\
\hline Tamandua tetradactyla ${ }^{2}$ & Southern Tamandua & 21 & $\mathrm{Ct}, \mathrm{Vi}$ & - & - & LC \\
\hline \multicolumn{7}{|l|}{ CINGULATA } \\
\hline Dasypus novemcinctus, & Nine-banded Armadillo & 78 & $\mathrm{Ct}, \mathrm{Tr}, \mathrm{Bu}$ & - & - & LC \\
\hline Euphractus sexcinctus ${ }^{1,2}$ & Six-banded Armadillo & 35 & $\mathrm{Ct}, \mathrm{Tr}, \mathrm{Vi}$ & - & - & LC \\
\hline Tolypeutes tricinctus ${ }^{1,2}$ & Three-banded Armadillo & 52 & $\mathrm{Ct}, \mathrm{Tr}, \mathrm{Vi}$ & EN & EN & VU \\
\hline \multicolumn{7}{|l|}{ PERISSODACTYLA } \\
\hline Equus asinus ${ }^{1,2}$ & Donkey & 43 & $\mathrm{Ct}, \mathrm{Tr}, \mathrm{Vi}$ & - & - & - \\
\hline Equus caballus, & Horse & 6 & $\mathrm{Ct}, \mathrm{Tr}, \mathrm{Vi}$ & - & - & - \\
\hline \multicolumn{7}{|l|}{ ARTIODACTYLA } \\
\hline Mazama gouazoubira ${ }^{1,2}$ & Gray Brocket Deer & 348 & $\mathrm{Ct}, \mathrm{Tr}, \mathrm{Vi}, \mathrm{Sc}$ & - & - & LC \\
\hline Pecaritajacu, & Collared Peccary & 226 & $\mathrm{Ct}, \mathrm{Tr}, \mathrm{Vi}, \mathrm{Sc}$ & NT & - & LC \\
\hline Tayassu pecari ${ }^{2}$ & White-lipped Peccary & 0 & $\mathrm{Ct}$ & EN & VU & VU \\
\hline Bos taurus $^{1,2}$ & Cattle & 454 & $\mathrm{Ct}, \mathrm{Tr}, \mathrm{Vi}$ & - & - & - \\
\hline Capra aegagrus hircus $^{2}$ & Goat & 47 & $\mathrm{Ct}, \mathrm{Tr}, \mathrm{Vi}$ & - & - & - \\
\hline Ovis aries $^{1,2}$ & Sheep & 9 & $\mathrm{Ct}, \mathrm{Tr}, \mathrm{Vi}$ & - & - & - \\
\hline \multicolumn{7}{|l|}{ PRIMATES } \\
\hline Alouatta caraya ${ }^{2}$ & Black Howler Monkey & 0 & $\mathrm{Vi}$ & - & - & $\mathrm{LC}$ \\
\hline Callithrix jacchus $^{2}$ & Common Marmoset & 0 & Vi & - & - & $\mathrm{LC}$ \\
\hline \multicolumn{7}{|l|}{ CARNIVORA } \\
\hline Canis familiaris, & Dog & 85 & $\mathrm{Ct}, \mathrm{Tr}, \mathrm{Vi}$ & - & - & - \\
\hline Cerdocyon thous ${ }^{1,2}$ & Crab-eating Fox & 256 & $\mathrm{Ct}, \mathrm{Tr}, \mathrm{Vi}$ & - & - & $\mathrm{LC}$ \\
\hline Leopardus pardalis & Ocelot & 217 & $\mathrm{Ct}, \mathrm{Tr}, \mathrm{Sc}$ & VU & - & LC \\
\hline Leopardus tigrinus, & Oncilla & 65 & $\mathrm{Ct}, \mathrm{Tr}$ & VU & EN & VU \\
\hline Panthera onca $a^{1,2}$ & Jaguar & 15 & $\mathrm{Ct}, \mathrm{Tr}, \mathrm{Sc}$ & $C R$ & VU & NT \\
\hline Puma concolor ${ }^{1,2}$ & Puma & 35 & $\mathrm{Ct}, \mathrm{Tr}$ & VU & VU & LC \\
\hline Herpailurus yagouaroundi, & Jaguarundi & 36 & $\mathrm{Ct}, \mathrm{Tr}$ & VU & VU & $\mathrm{LC}$ \\
\hline Conepatus semistriatus ${ }^{1,2}$ & Striped Hog-nosed Skunk & 21 & $\mathrm{Ct}, \mathrm{Tr}$ & - & - & LC \\
\hline Eira barbara ${ }^{1,2}$ & Tayra & 1 & $\mathrm{Ct}, \mathrm{Vi}$ & - & - & LC \\
\hline Galictis cuja $a^{1,2}$ & Lesser Grison & 0 & $\operatorname{Tr}$ & - & - & LC \\
\hline Nasua nasua ${ }^{1,2}$ & Coati & 2 & $\mathrm{Ct}, \mathrm{Vi}$ & - & - & LC \\
\hline Procyon cancrivorus ${ }^{1,2}$ & Crab-eating Raccoon & 2 & $\mathrm{Ct}, \mathrm{Tr}$ & - & - & LC \\
\hline \multicolumn{7}{|l|}{ RODENTIA } \\
\hline Galea spixii ${ }^{1,2}$ & Spix's Cavy & 835 & $\mathrm{Ct}, \mathrm{Vi}$ & - & - & LC \\
\hline Kerodon rupestris ${ }^{1,2}$ & Rock Cavy & 352 & $\mathrm{Ct}, \mathrm{Tr}, \mathrm{Vi}, \mathrm{Sc}$ & - & - & $\mathrm{LC}$ \\
\hline Dasyprocta nigriclunis ${ }^{1,2}$ & Black-rumped Agouti & 302 & $\mathrm{Ct}, \mathrm{Tr}$ & - & - & - \\
\hline Thrichomys sp. $^{2}$ & Common Punaré & 63 & $\mathrm{Ct}, \mathrm{Vi}$ & 一 & 一 & 一 \\
\hline
\end{tabular}

\footnotetext{
1,2 Species records from studies 1 and 2 .
}

For sixteen years the region has been proposed for the creation of Boqueirão da Onça National Park, process under responsibility of the Chico Mendes Institute for Biodiversity Conservation - ICMBio, under cooperation of the Ministry of Environment - MMA. However, the process faced successive changes due to different interests of land use and occupation of the region which culminated in the creation of a mosaic of different kinds of protected areas with a decrease of over $50 \%$ on the integral protected area, originally proposed.

In 2018, the creation of a mosaic of Protected Areas on the study area, Boqueirão da Onça National Park $\left(3,470 \mathrm{~km}^{2}\right)$, Boqueirão da Onça Environmental Protected Area $\left(5,050 \mathrm{~km}^{2}\right)$ and Toca da Boa Vista Wildlife Zone $\left(116 \mathrm{~km}^{2}\right)$ is crucial to guarantee the preservation of some unique conditions present in the region, including different types of soils (texture, formation and morphology), geological aspects (e.g., granites and micaxists). In addition, the largest caves of Latin America, Toca da Boa Vista and Toca da Barriguda (Cruz et al., 2018), water resources, different rock arts (painted or drawn pictographs, engraved or carved petroglyphs) (Whitley, 2005) of prehistoric times (most of them still unknown by researchers) and endemic species of fauna and flora of the Caatinga (Ramos et al., 2010).

Long-term studies are recommended to monitor mammals and other groups of fauna in the region, as well as to assess and evaluate the abundance of species of major interest for conservation. In addition, the information presented may be important to support National 
Action Plan for the Conservation of Species, and the elaboration of the Management Plan for Boqueirão da Onça National Park, to mitigate human wildlife conflicts, to promote the integration of the protected area into the economic and social life of neighboring communities and to guarantee the persistence of wildlife species.

\section{ACKNOWLEDGMENTS}

We are grateful to the Neotropical Grassland Conservancy for providing memorial grants, Rufford Foundation for a small grant (project 18442-1) and ENEL Green Power for financial resource. We also thank the Coordenação de Aperfeiçoamento de Pessoal de Nível Superior (CAPES) for providing grants to DMD. We are also grateful to Professor Adriano Paglia of the Federal University of Minas Gerais for logistic support. We also thank the Mariano Neto F. de Jesus and Ismael A. da Silva for assistance in field activities. The anonymous reviewers kindly reviewed and helped to improve the manuscript.

\section{REFERENCES}

Albuquerque, U.P.; Araújo, E.L.; El-Deir, A.C.A.; Lima, A.L.A.L.; Souto, A.; Bezerra, B.M.; Ferraz, E.M.N.; Freire, E.M.X.; Sampaio, E.V.S.B.; LasCasas, F.M.G.; Moura, G.J.B.; Pereira, G.A.; Melo, J.G.; Ramos, M.A.; Rodal, M.J.N.; Schiel, N.; Lyra-Neves, R.M.; Alves, R.R.N.; Azevedo-Júnior, S.M.; Telino Jr., W.R. \& Severi, W. 2012. Caatinga revisited: Ecology and Conservation of an important Seasonal Dry Forest. The Scientific World Journal, (205182): 1-18. DOI

Álvares, C.A.; Stape, J.L.; Sentelhas, P.C. \& Moraes Gonçalves, J.L. 2013a. Modeling monthly mean air temperature for Brazil. Theoretical and Applied Climatology, 113: 407-427.

Álvares, C.A.; Stape, J.L.; Sentelhas, P.C.; Gonçalves J.L.M. \& Sparovek, G. 2013b. Köppen's climate classification map for Brazil. Meteorologische Zeitschrift, 22: 711-728.

Astete, S.; Sollmann, R. \& Silveira, L. 2008. Comparative ecology of jaguars in Brazil. Cat News Special, 4: 9-14.

Athreya, V.; Odden, M.; Linnell, J.D.C.; Krishnaswamy, J. \& Karanth, U. 2013. Big cats in our backyards: persistence of large carnivores in a human dominated landscape in India. Plos One, 8: e57872.

Banda-R, K.; Delgado-Salinas, A.; Dexter, K.G.; Linares-Palomino, R, OliveiraFilho, A.; Prado, D.; Pullan, M.; Quintana, C.; Riina, R.; Rodríguez M., G.M.; Weintritt, J.; Acevedo-Rodríguez, P.; Adarve, J.; Álvarez, E.; Aranguren B., A.; Arteaga, J.C.; Aymard, G.; Castaño, A.; Ceballos-Mago, N.; Cogollo, Á.; Cuadros, H.; Delgado, F.; Devia, W.; Dueñas, H.; Fajardo, L.; Fernández, Á.; Fernández, M.Á.; Franklin, J.; Freid, E.H.; Galetti, L.A.; Gonto, R.; González-M., R.; Graveson, R.; Helmer, E.H.; Idárraga, Á.; López, R.; Marcano-Veja, H.; Martínez, O.G.; Maturo, H.M.; McDonald, M.; McLaren, K.; Melo, 0.; Mijares, F.; Mogni, V.; Molina, D.; Moreno, N. del P.; Nassar, J.M.; Neves, D.M.; Oakley, L.J.; Oatham, M.; Olvera-Luna, A.R.; Pezzini, F.F.; Dominguez, 0.J.R.; Ríos, M.E.; Rivera, 0.; Rodríguez, N.; Rojas, A.; Särkinen, T.; Sánchez, R.; Smith, M.; Vargas, C.; Villanueva, B. \& Toby Pennington, R.T. 2016. Plant diversity patterns in neotropical dry forests and their conservation implications. Science, 353: 1383-1387.

Becker, M. \& Dalponte, J.C. 2013. Rastros de mamiferos silvestres brasileiros: um guia de campo. Rio de Janeiro, Technical Books.
Bernard, E.; Paese, A.; Machado, R.B. \& Aguiar, L.M.S. 2014. Blown in the wind: bats and wind farms in Brazil. Natureza \& Conservação, 12: 106-111.

Borges, P.A.L. \& Tomás, W.M. 2008. Guia de rastros e outros vestígios de mamíferos do Pantanal. Corumbá, Embrapa Pantanal.

Campos, C.B.; Esteves, C.F.; Ferraz, K.M.P.M.B.; Crawshaw Jr., P.G. \& Verdade, L.M. 2007. Diet of free-ranging cats and dogs in a suburban and rural environment, south-eastern Brazil. Journal of Zoology, 273: 14-20.

Carmignotto, A.P. \& Astúa, D. 2017. Mammals of the Caatinga: Diversity, Ecology, Biogeography, and Conservation. In: Silva, J.; Leal, I. \& Tabarelli, M. (Eds.). Caatinga: The largest tropical dry forest region in South America. Cham, Springer. p. 211-254.

Cassano, C.R.; Almeida-Rocha, J.M.; Alvarez, M.R.; São Bernardo, C.S.; Bianconi, G.V.; Campiolo, S.; Campos, C.B.; Danilewicz, D.; Falcão, F.C.; García, F.V.; Giné, G.A.F.; Guidorizzi, C.E.; Jerusalinsky, L.; Pendu, Y.L.; Marcondes, M.C.C.; Melo, V.L.; Mendes, F.R.; Miretzki, M.; Neves, L.G.; Oliveira, L.C.; Pereira, A.R.; Silva, K.F.M.; Reis, M.S.; Vleeschouwer, K.M.; Vieira, E.M. \& lack-Ximenes, G.E. 2017. Primeira avaliação do status de conservação dos mamíferos do estado da Bahia, Brasil. Oecologia Australis, 21: 156-170.

Castelletti, C.H.M.; Silva; J.M.C.D.; Tabarelli, M. \& Santos, A.M.M. 2003. Quanto ainda resta da Caatinga? Uma estimativa preliminar. In: Silva, JMC.; Tabarelli, M.; Fonseca, M.T. \& Lins, L.V. (Orgs.). Biodiversidade da Caatinga: áreas e ações prioritárias para a conservação. Brasília, Ministério do Meio Ambiente. p. 91-100.

Chapron, L.; Kaczensky, P.; Linnell, J.D.; Von Arx, H.; Huber, D.; Andrén, H.; López-Bao, J.V.; Adamec, H.; Alvares, F.; Anders, 0.; Balčiauskas, G.; Balys, V.; Bedo, P.; Bego, F.; Blanco, J.C.; Atrelados, U.; Brøseth, H.; Bufka, G.; Bunikyte, R.; Ciucci, P.; Dutsov, A.; Engleder, T.; Fuxjäger, C.; Groff, C.; Holmala, K.; Hoxha, B.; Iliopoulos, Y.; Ionescu, O.; Jeremic, J.; Jerina, K.; Kluth, G.; Knauer, F.; Kojola, I.; Kos, I.; Krofel, M.; Kubala, J.; Kunovac, S.; Kusak, J.; Kutal, M.; Liberg, 0.; Majic, A.; Männil, P.; Manz, R.; Marboutin, E.; Marucco, F.; Melovski, D.; Mersini, K.; Mertzanis, Y.; Mysłajek, R.W.; Nowak, S.; Odden, J.; Ozolins, J.; Palomero, L.; Paunović, M.; Persson, J.; Potočnik, H.; Quenette, P.Y.; Rauer, L.; Reinhardt, I.; Rigg, R.; Ryser, A.; Salvatori, V.; Skrbinšek, T.; Stojanov, A.; Swenson, J.E.; Szemethy, L.; Trajce, A.; Tsingarska-Sedefcheva, E.; Váňa, M.; Veeroja, R.; Wabakken, P.; Wölfl, M.; Wölfl, S.; Zimmermann, F.; Zlatanova, D. \& Boitani, G. 2014. Recovery of large carnivores in Europe's modern human-dominated landscapes. Science, 346: 1517-1519.

Coimbra-Filho, A.F. \& Câmara, I.G. 1996. Os limites originais do bioma Mata Atlântica na região Nordeste do Brasil. Rio de Janeiro, FBCN.

Costa, G.F.; Paula, J.; Petrucci-Fonseca, F. \& Álvares, F. 2017. The Indirect Impacts of Wind Farms on Terrestrial Mammals - Insights from the Disturbance and Exclusion Effects on Wolves (Canis lupus). In: Mascarenhas, M.; Marques, A.T.; Ramalho, R.; Santos, D.; Bernardinho, J. \& Fonseca, C. (Eds.). Biodiversity and wind farms in Portugal: Current knowledge and insights for an integrated impact assesment process. Cham, Springer International Publishing. p. 111-134.

Costa, R.C.; Araújo, F.S. \& Lima-Verde, L.W. 2007. Flora and life-form spectrum of deciduous thorn woodland (Caatinga) in northeastern, Brazil. Journal of Arid Environments, 68: 237-247.

Crooks, K.R.; Burdett, C.L.; Theobald, D.M.; Rondini, C. \& Boitani, L. 2011. Global patterns of fragmentation and connectivity of mammalian carnivore habitat. Philosophical Transactions: Biological Sciences, 366: 2642-2651.

Cruz, I.M.; Barros, L.C. \& Araújo, A.V. 2018. Diagnóstico de impactos ambientais adversos causados pela visitação da população na Gruta do Sumidouro - Campo Formoso (BA). Scientia Plena, 14: 1-12.

Cuarón, A.D. 2000. A global perspective on habitat disturbance and tropical rainforest mammals. Conservation Biology, 14: 1574-1579. 
Curi, N.H.A.; Massara, R.L.; Oliveira Paschoal, A.M.; Soriano-Araújo, A.; Lobato, Z.I.P.; Demétrio, G.R.; Chiarello, A.G. \& Passamani, M. 2016. Prevalence and risk factors for viral exposure in rural dogs around protected areas of the Atlantic forest. BMC Veterinary Research, 12: 12-21.

Deiciellos, A.C. 2016. Mammals of four Caatinga areas in northeastern Brazil: Inventory, species biology, and community structure. Check List, 12: 1-15.

Di Marco, M.; Buchanan, G.M.; Szantoi, Z.; Holmgren, M.; Marasini, G.G.; Gross, D.; Tranquilli, S.; Boitani, L. \& Rondinini, C. 2014. Drivers of extinction risk in African mammals: the interplay of distribution state, human pressure, conservation response and species biology. Philosophical Transactions of the Royal Society of London, B: Biological Sciences, 369(1643): 1-12. (artigo 20130198).

Di Minin, E.; Slotow, R.; Hunter, L.T.B.; Pouzols, F.M.; Toivonen, T.; Verburg, P.H.; Leader-Williams, N.; Petracca, L. \& Moilanen, A. 2016. Global priorities for national carnivore conservation under land use change. Scientific Reports, 6(23814): 1-9.

Dias, D.M. \& Bocchiglieri, A. 2016. Riqueza e uso do habitat por mamíferos de médio e grande porte na Caatinga, nordeste do Brasil. Neotropical Biology and Conservation, 11:38-46.

Dias, D.M.; Guedes, P.G.; Silva, S.S.P. \& Sena, L.M. 2017. Diversity of nonvolant mammals in a Caatinga area in northeastern Brazil. Neotropical Biology and Conservation, 12: 200-208.

Dias, D.M.; Massara, R.L.; Campos, C.B. \& Rodrigues, F.H.G. 2019. Human activities influence the occupancy probability of mammalian carnivores in the Brazilian Caatinga. Biotropica, 51: 253-265.

Dudley, N. 2008. Directrices para la aplicación de las categorías de gestión de áreas protegidas. Gland, Suiza UICN. 116p.

Evangelista, A.R.S. 2011. 0 processo de desmatamento do bioma caatinga: riscos e vulnerabilidades socioambientais no território de identidade do sisal. Revista Geográfica de América Central, 2: 1-13.

Freitas, E.B.; De-Carvalho, C.B. \& Ferrari, S.F. 2011. Abundance of Callicebus barbarabrownae (Hershkovitz, 1990), (Primates: Pitheciidae) and other nonvolant mammals in a fragment of arboreal Caatinga in northeastern Brazil. Mammalia, 75: 1-5.

Freitas, E.B.; De-Carvalho, C.B.; Beltrão-Mendes, R.; Rocha, S.M.; Marques, E.L.N.; Ruiz-Esparza, J.; Rocha, P.A. \& Ferrari, S.F. 2017. Nonvolant mammals of the Grota do Angico Natural Monument, northeast of Brazil: a complementary approach to the small species. Natureza Online, 15: 49-57.

Gariglio, M.A.; Sampaio, E.V.S.B.; Cestaro, L.A. \& Kageyama, P.Y. 2010. Uso sustentável e conservação dos recursos florestais da caatinga. Brasília, Ministério do Meio Ambiente, Secretaria de Biodiversidade e Florestas.

Guedes, P.G.; Silva, S.S.P.; Camardella, A.R.; Abreu, M.F.G.; Borges-Nojosa, D.M.; Silva, J.A.G. \& Silva, A.A. 2000. Diversidade de Mamíferos do Parque Nacional de Ubajara (Ceará, Brasil). Mastozoologia Neotropical, 7: 95-100.

Helldin, J.0.; Jung, J.; Neumann, W.; Ollsson, M.; Skarin, A. \& Widemo, F. 2012. The impact of wind power on terrestrial mammals: A synthesis. Bromma, Swedish Environmental Protection Agency.

Instituto Brasileiro de Geografia e Estatística (IBGE). 2012. Manual técnico da vegetação brasileira. 2 . ed. Rio de Janeiro, Instituto Brasileiro de Geografia e Estatística. (Manuais Técnicos de Geociências, № 1)

Jones, K.E. \& Safi, K. 2011. Ecology and evolution of mammalian biodiversity. Philosophical Transactions of the Royal Society of London, B. Biological Sciences, 366: 2451-2461.

Karanth, K.U. \& Chellam, R. 2009. Carnivore conservation at the crossroads. Oryx, 43: 1-2.

Kitchener, A.C.; Breitenmoser-Würsten, C.H.; Eizirik, E.; Gentry, A.; Werdelin, L.; Wilting, A.; Yamaguchi, N.; Abramov, A.V.; Christiansen, P.; Driscoll, C.; Duckworth, J.W.; Johnson, W.; Luo, S.-J.; Meijaard, E.; O'Donoghue, P.; Sanderson, J.; Seymour, K.; Bruford, M.; Groves, C.; Hoffmann, M.;
Nowell, K.; Timmons, Z. \& Tobe, S. 2017. A revised taxonomy of the Felidae. The final report of the Cat Classification Task Force of the IUCN/ SSC Cat Specialist Group. Cat News Special Issue, 11: 1-80p.

Lacerda, A.C.R.; Tomas, W.M. \& Marinho-Filho, J. 2009. Domestic dogs as an edge effect in the Brasilia National Park, Brazil interactions with native mammals. Animal Conservation, 12: 477-487.

Marinho, P.H.; Bezerra, D.; Antongiovanni, M.; Fonseca, C.R. \& Venticinque, E.M. 2018. Mamíferos de médio e grande porte da caatinga do Rio Grande do Norte, nordeste do Brasil. Mastozoología Neotropical, 25: 345-362.

Massara, R.L.; Paschoal, A.M. do; Bailey, L.L.; Doherty, P.F.; Hirsch, A. \& Chiarello, A.G. 2018. Factors influencing ocelot occupancy in Brazilian Atlantic Forest reserves. Biotropica, 50: 125-134.

Ministério do Meio Ambiente (MMA). 2018. Livro Vermelho da Fauna Brasileira Ameaçada de Extinção: Mamíferos. Brasília, ICMBio/MMA. v. 2,625p.

Ministério do Meio Ambiente (MMA). 2016. Ministério do Meio Ambiente. Resultados da 2a atualização das Áreas e Ações Prioritárias para Conservação, Uso Sustentável e Repartição dos Benefícios da Biodiversidade dos biomas Cerrado e Pantanal realizado em 2012, e da Caatinga, realizado em 2015. Áreas Prioritárias para a Conservação, Uso Sustentável e Repartição de Benefícios da Biodiversidade Brasileira: Atualização - Portaria MMA № 9, de 23 de janeiro de 2007. Brasília, Ministério do Meio Ambiente, Secretaria de Biodiversidade e Florestas. 301p. Available at: http://www.mma.gov. br/quem-\%C3\%A9-quem/item/10724. Access in: 14/02/2018.

Oliveira, G. \& Diniz-Filho, J.A.F. 2010. Spatial patterns of terrestrial vertebrates richness in Brazilian semiarid, Northeastern Brazil: Selecting hypotheses and revealing constraints. Journal of Arid Environments, 74: 1418-1426.

Oliveira, G.; Araújo, M.B.; Rangel, T.F.; Alagador, D. \& Diniz-Filho, J.A.F. 2012. Conserving the Brazilian semiarid (Caatinga) biome under climate change. Biodiversity and Conservation, 21(11): 2913-2926.

Pardini, R.; Ditt, E.; Cullen Jr., L.; Bassi, C. \& Rudran, R. 2003. Levantamento rápido de mamíferos terrestres de médio e grande porte. In: Cullen Jr., L.; Rudran, R. \& Pádua, C.V. (Eds.). Métodos de estudo em biologia da conservação e manejo da vida silvestre. Curitiba, Universidade Federal do Paraná.

Paula, R.C.; Campos, C.B. \& Morato, R.G. 2011. Mastofauna da Bacia Hidrográfica do Rio São Francisco: Mamíferos de médio e grande porte. In: Ministério do Meio Ambiente - MMA. (Org.). Diagnóstico do macrozoneamento ecológico-econômico da Bacia Hidrográfica do Rio São Francisco. Brasília, MMA. p. 266-281.

Paula, R.C.; Desbiez, A. \& Cavalcanti, S. 2013. Plano de ação nacional para a conservação da onça-pintada. Brasília, ICMBio - Instituto Chico Mendes de Conservação da Biodiversidade.

Pereira, C.J. \& Peixoto, R.S. 2017. Levantamento de mamíferos terrestres em uma área de caatinga em Senhor do Bonfim, Bahia. Revista Brasileira de Zoociências, 18: 33-44.

Porras, L.P.; Vazquez, L.B.; Sarmiento-Aguilar, R.; Douterlungne, D. \& Valenzuela-Galván, D. 2016. Influence of human activities on some medium and large-sized mammals' richness and abundance in the Lacandon Rainforest. Journal for Nature Conservation, 34: 75-81.

Queiroz, L.P.; Cardoso, D.; Fernandes, M.F. \& Moro, M.F. 2017. Diversity and Evolution of Flowering Plants of the Caatinga Domain. In: Silva, J.; Leal, I. \& Tabarelli, M. (Eds.). Caatinga: the largest tropical dry forest region in South America. Cham, Springer. p. 23-63.

Ramos, R.R.D.; Lopes, H.L.; Melo Júnior, J.C.F.; Candeias, A.L.B. \& SiqueiraFilho, J.A. 2010. Aplicação do índice da vegetação por diferença normalizada (NDVI) na avaliação de áreas degradadas e potenciais para unidades de conservação. In: Simpósio Brasileiro de Ciências Geodésicas e Tecnologias da Geoinformação, $3^{\circ}$. Anais. Recife, Universidade Federal de Pernambuco. p. 27-30. 
Ribeiro-Neto, J.D.; Arnan, X.; Tabarelli, M. \& Leal, I.R. 2016. Chronic anthropogenic disturbance causes homogenization of plant and ant communities in the Brazilian Caatinga. Biodiversity and Conservation, 25: 943-956.

Rocha, P.A.; Ruiz-Esparza, J.; Beltrão-Mendes, R., Ribeiro, A.S.; Campos, B.A.T.P. \& Ferrari, S.F. 2014. Nonvolant mammals in habitats of the Caatinga scrub and cloud forest enclave at Serra da Guia, state of Sergipe. Revista Brasileira de Zoociências, 16: 93-103.

Schiaffini, M.l.; Gabrielli, M.; Prevosti, F.J.; Cardos, Y.P.; Castillo, D.; Bo, R.; Casanave, E. \& Lizarralde, M. 2013. Taxonomic status of southern South American Conepatus (Carnivora - Mephitidae). Zoological Journal of the Linnean Society, 167: 327-344.

Santos, J.C.; Leal, I.R.; Almeida-Cortez, J.S.; Fernandes, W. \& Tabarelli, M. 2011. Caatinga: the scientific negligence experienced by a dry tropical Forest. Tropical Conservation Science, 4: 276-286.

Silveira, L.F.; Beisiegel, B.M.; Curcio, F.F.; Valdujo, P.H.; Dixo, M.; Verdade, V.K.; Mattox, G.M.T. \& Cunningham, P.T.M. 2010. Para que servem os inventários de fauna? Estudos Avançados, 24: 173-207.

Siqueira Filho, J.A.; Conceição, A.A.; Rapini, A.; Coelho, A.O.P.; Zuntini, A.R.; Coutinho, A.J.; Vieira, A.O.S.; Prata, A.P.N.; Machado, A.F.P.; Alves-Araújo, A.G.; Melo, A.L.; Amorim, A.M.A.; Fontana, A.P.; Moreira, A.D.R.; Lima, C.T.; Proença, C.E.B.; Luz, C.L.; Kameyama, C.; Caires, C.S.; Bove, C.P.; Mynssen, C.M.; Sá, C.F.C.; Melo, E.; Souza, E.B.; Leme, E.M.C.; FirettiLeggieri, F.; Salimena, F.R.G.; França, F.; Rainer, H.; Faria Júnior, J.E.Q.; Maciel, J.R.; Lopes, J.C.; Braga, J.M.A.; Stehmann, J.R.; Jardim, J.G.; Pereira, J.F.; Pastore, J.F.B.; Valls, J.F.M.; Melo, J.I.M.; Pirani, J.R.; Silva, J.A.; Paula-Souza, J.; Cardoso, L.J.T.; Matias, L.Q.; Lohmann, L.G.; Queiroz,
L.P.; Oliveira, M.A.; Sobral, M.E.G.; Silva, M.J.; Meiado, M.V.; Coelho, M.A.N.; Costa e Silva, M.B.; Mamede, M.C.H.; Lucena, M.F.A.; Pessoa, M.C.R.; Loiola, M.I.B.; Arbo, M.M.; Barbosa, M.R.V.; Marchioretto, M.S.; Buril, M.T.; Bovini, M.G.; Bueno, N.C.; Fiaschi, P.; Borges, R.A.X.; Forzza, R.C.; Sebastiani, R.; Mello-Silva, R.; Couto, R.S.; Lima, R.B.; Pereira, R.C.A.; Marquete, R.; Barreto, R.C.; Xavier, S.R.S.; Profice, S.R.; Cavalcanti, T.B.; Silva, T.R.S.; Pott, V.J.; Klein, V.L.G. \& Souza, V.C. 2012. Flora das Caatingas do Rio São Francisco. In: Siqueira Filho, J.A. (Org.). Flora das Caatingas do Rio São Francisco: história natural e conservação. Rio de Janeiro, Andrea Jakobsson Estúdio Editorial. p. 446-542.

Sunderland, T.; Apgaua, D.; Baldauf, C.; Blackie, R.; Colfer, C.; Cunningham, A.B.; Dexter, K.; Djoudi, H.; Gautier, D.; Gumbo, D.; Ickowitz, A.; Kassa, H.; Parthasarathy, N.; Pennington, R.T.; Paumgarten, F.; Pulla, S.; Sola, P.; Tng, D.; Waeber, P. \& Wilmé, L. 2015. Global dry forests: a prologue. International Forestry Review, 17: 1-9.

Wemmer, C.; Hunz, T.H.; Lundie-Jenkins, G. \& McShea, W.J. 1996. Mammalian signs. In: Wilson, D.E.;. Cole, F.R.; Nichols, J.D.; Rudran, R. \& Foster, M.S. (Eds.). Measuring and monitoring biological diversity. Standard methods for mammals. Washington, Smithsonian Institution Press. p. 157-176.

Whitley, D.S. 2005. Introduction to Rock Art Research. Walnut Creek, Left Coast Press.

Wilson, D.E. \& Reeder D 2005. Mammal Species of the World: A Taxonomic and Geographic. Johns Hopkins University Press, Baltimore, 2142 p.

Wozencraft, W.C. 2005. Order Carnivora. In: Wilson, D.E. \& Reeder, D.M. (Eds.). Mammal Species of the World: A Taxonomic and Geographic. Johns Hopkins University Press, Baltimore, p. 532-628. 